\title{
Insurance Claim
}

National Cancer Institute

\section{Source}

National Cancer Institute. Insurance Claim. NCI Thesaurus. Code C154422.

Notification to an insurance company requesting payment of an amount due under the terms of the policy. 